\title{
Molecular evolution of dengue virus types 1 and 4 in Korean travelers
}

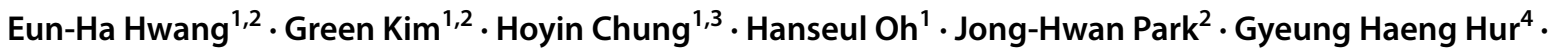 \\ JungJoo Hong ${ }^{1} \cdot$ Bon-Sang Koo ${ }^{1}$ (C)
}

Received: 3 November 2020 / Accepted: 8 December 2020 / Published online: 11 February 2021

(c) The Author(s) 2021

\begin{abstract}
Dengue virus (DV) is a mosquito-borne virus that is endemic to many tropical and subtropical areas. Recently, the annual incidence of DV infection has increased worldwide, including in Korea, due to global warming and increased global travel. We therefore sought to characterize the molecular and evolutionary features of DV-1 and DV-4 isolated from Korean overseas travelers. We used phylogenetic analysis based on the full coding region to classify isolates of DV-1 in Korea into genotype I (43251, KP406802), genotype IV (KP406803), and genotype V (KP406801). In addition, we found that strains of DV-4 belonged to genotype I (KP406806) and genotype II (43257). Evidence of positive selection in DV-1 strains was identified in the C, prM, NS2A, and NS5 proteins, whereas DV-4 showed positive selection only in the non-structural proteins NS2A, NS3, and NS5. The substitution rates per site per year were $5.58 \times 10^{-4}$ and $6.72 \times 10^{-4}$ for DV-1 and DV-4, respectively, and the time of the most recent common ancestor was determined using the Bayesian skyline coalescent method. In this study, the molecular, phylogenetic, and evolutionary characteristics of Korean DV-1 and DV-4 isolates were evaluated for the first time.
\end{abstract}

\section{Introduction}

Dengue fever is a major mosquito-borne viral illness that causes significant public health problems in subtropical and tropical regions of the world [1]. Dengue virus (DV) is commonly transmitted among humans by two mosquito vectors, Aedes aegypti and Aedes albopictus [2]. Global warming

Handling Editor: Zhenhai Chen.

Supplementary Information The online version contains supplementary material available at https://doi.org/10.1007/s0070 5-021-04973-8.

JungJoo Hong

hong75@kribb.re.kr

Bon-Sang Koo

porco9@kribb.re.kr

1 National Primate Research Center, Korea Research Institute of Bioscience and Biotechnology, Cheongju, Republic of Korea

2 Laboratory of Animal Medicine, College of Veterinary Medicine, Chonnam National University, Gwangju, Republic of Korea

3 Department of Microbiology, College of Natural Sciences, Chungbuk National University, Cheongju, Republic of Korea

4 Agency for Defense Development, Daejeon, Republic of Korea and urbanization have fueled the population growth of these vectors and broadened their habitat. During the past three decades, the incidence of dengue fever has increased by more than $300 \%$ in more than 100 countries [3-5]. There are 2.9 million dengue infections and 5,906 deaths reported in Southeast Asia each year [6]. For this reason, the World Health Organization has designated dengue infection as one of the top 17 tropical diseases [7].

DV, a member of the family Flaviviridae, has a singlestranded positive-sense RNA genome that encodes three structural proteins (capsid [C], pre-membrane [prM], envelope $[\mathrm{E}]$ ) and seven non-structural proteins (non-structural [NS] 1, NS2A, NS2B, NS3, NS4A, NS4B, NS5) [1]. DVs are classified into four distinct serotypes (DV-1, DV-2, DV-3, and DV-4) and subdivided into several genotypes within each serotype. Significantly high genetic variation is commonly observed in the DV genome, with $60-70 \%$ amino acid sequence identity shared between serotypes [2]. This high genetic variability is closely related to the highly variable pathogenicity and transmissibility of DV [8].

Dengue has a wide spectrum of clinical severity, from asymptomatic through a self-limiting febrile illness (dengue fever) to life-threatening severe infections such as dengue hemorrhagic fever (DHF) and dengue shock syndrome (DSS). The mechanisms underlying severe dengue infections are not completely understood, but an antibody-dependent 
enhancement phenomenon and infection with particularly virulent virus strains are known to correlate with severe dengue infection [9-11]. Specific amino acid changes in DV proteins are closely associated with altered virulence. For instance, mutation of amino acids 124 and 128 of the E protein, amino acid 64 of NS2A, or amino acid 55 of NS2B can increases DV virulence $[11,12]$.

Since the first case of dengue fever was reported in South Korea in 1995, DV infections have been increasingly reported by travelers returning from dengue-endemic countries [13]. A. albopictus was recently identified as a mosquito vector for dengue infection in Korea. The expanding distribution of this mosquito in urban areas increases the likelihood of outbreaks in Korea [14-16]. Indeed, autochthonous dengue infections have been reported in Japan and some European countries at approximately the same latitudes as in Korea. DV-1 and DV-4 have been reported to cause severe dengue fever at a high rate of incidence in Asian countries $[17,18]$. Therefore, surveillance of these serotypes is necessary, but information on Korean DVs is very limited. For this report, we performed molecular and evolutionary analysis of DV-1 and DV-4.

\section{Materials and methods}

\section{Viruses and sequencing}

Isolates of DV-1 and DV-4 (NCCP43251, NCCP43257) were obtained from the National Culture Collection for Pathogens (Cheongju, Korea). These viruses were isolated from serum samples from Korean overseas travelers (Table 1). The virus was cultivated on a monolayer of Vero E6 cells (ATCC CRL-1586) for propagation in minimal essential medium (Gibco, Life Technologies, NY, USA) containing $2 \%$ fetal bovine serum and $1 \%$ penicillin $(100 \mathrm{IU} / \mathrm{ml}) /$ streptomycin $(100 \mu \mathrm{g} / \mathrm{ml})(\mathrm{Gibco})$ at $37{ }^{\circ} \mathrm{C}$ and $5 \% \mathrm{CO}_{2}$. Viral RNA was extracted from the supernatant of the DVinfected Vero E6 cells using a QIAamp Viral RNA Mini Kit (QIAGEN, CA, USA) according to the manufacturer's instructions. Reverse transcription (RT)-PCR was performed using a QIAGEN OneStep RT-PCR Kit with modified PCR primer sets targeting the full genome sequences of DV-1 and
DV-4 (Supplementary Table S1) [19]. The PCR conditions as follows: reverse transcription at $45^{\circ} \mathrm{C}$ for 30 minutes and denaturation at $95{ }^{\circ} \mathrm{C}$ for 15 minutes, followed by 40 cycles of amplification $\left(94{ }^{\circ} \mathrm{C}\right.$ for 10 seconds, $46{ }^{\circ} \mathrm{C}$ for 30 seconds, and $68{ }^{\circ} \mathrm{C}$ for 3 minutes), and then a final elongation step at $68{ }^{\circ} \mathrm{C}$ for 10 minutes. The final amplicons, stained with SYBR $^{\circledR}$ Safe DNA Gel Stain (Invitrogen, USA), were visualized on $1.6 \%$ agarose gels with UV transillumination and purified using an Expin Gel SV kit (GeneAll, Seoul, Korea). The purified products were then sequenced by the Sanger method using an ABI 3730XL System (Macrogen, Seoul, Korea). All procedures were conducted in a Biosafety Level 2 laboratory.

\section{Phylogenetic and sequence analysis}

The nucleotide sequences were trimmed using Bioedit software, version 7.0.5.3., and assembled using CLC Genomics Workbench 12.0 (QIAGEN). Multiple alignments of the complete coding regions were performed with DV reference genes (97 DV-1 and 57 DV-4), including previously reported Korean isolates, using the CLUSTAL W method. Maximum-likelihood phylogenetic analysis of DV-1 and DV-4 was performed using the Tamura Nei model with gamma distributed rates and 1,000 bootstrap replicates in Molecular Evolutionary Genetics Analysis (MEGA), version X [20]. The percentages of nucleotide and amino acid sequence identity among Korean isolates were calculated as pairwise $p$-distances.

\section{Bayesian evolutionary analysis}

The rate of nucleotide substitutions per site per year and the time to the most recent common ancestor (TMRCA) of 70 DV-1 and 54 DV-4 strains (differentiated based on their E protein sequences) was estimated using the Bayesian Markov chain Monte Carlo (MCMC) approach as implemented in the BEAST 2 package. Sequences with low quality or more than $99 \%$ identity as well as recombinant sequences were excluded from this analysis. The best-fit substitution model was selected using the Akaike information criterion and the Bayesian information criterion as implemented in CLC Genomics Workbench 12.0. The GTR + G + I model
Table 1 Information about the DV-1 and DV-4 strains analyzed in this study

\begin{tabular}{llllll}
\hline Type & Strain & Isolation year & Travel location & Source & Country of isolation \\
\hline DV-1 & KP406802 & 2015 & Indonesia & Human serum & South Korea \\
& 43251 & 2011 & Indonesia & Human serum & South Korea \\
& KP406803 & 2006 & Philippines & Human serum & South Korea \\
& KP406801 & 2004 & Singapore & Human serum & South Korea \\
DV-4 & 43257 & 2010 & Philippines & Human serum & South Korea \\
& KP406806 & - & - & Human serum & South Korea \\
\hline
\end{tabular}


(general time-reversible model with gamma-distributed rates of variation among sites and a proportion of invariable sites) was found to be the best-fit model for the DV-1 and DV-4 datasets. Three independent MCMC analyses, each with $60,000,000$ steps, were performed using the uncorrelated relaxed molecular clock with a Bayesian skyline coalescent prior, and they were combined with a burn-in value set to 10\% generations using Log Combiner 2.5.2. The convergence of the chain was evaluated and viewed using Tracer version 1.7.1 (http://tree.bio.ed.ac.uk/software/tracer/). Effective sample size (ESS) values greater than 200 indicated a sufficient level of sampling. The combined trees were annotated using Tree Annotator v.1.8.2 and visualized in Figtree 1.4.2.

\section{Selection pressure analysis}

Selection pressure was evaluated for $101 \mathrm{DV}-1$ and $59 \mathrm{DV}-4$ strains by different methods, using the datamonkey web server and the HyPhy package [21]. Sequences with ambiguous characteristics or high similarity ( $>99 \%$ identity) were excluded from this analysis. The ratio of synonymous to non-synonymous ( $\omega$ ratio) changes was calculated using the single-likelihood ancestor, fixed-effects likelihood, mixedeffects model of evolution, and fast unconstrained Bayesian approximation methods $[22,23]$. Selection pressure analysis was performed based on the full coding regions of the structural (C, prM, and E) and non-structural (NS1, NS2A, NS2B, NS3, NS4A, NS4B, and NS5) genes. Low $\omega$ ratios (0.060-0.081) were considered an indication of negative selection. Positive and negative selection at each site were analyzed based on statistical significance ( $p$-value $<0.1$ or posterior probability $<0.9)$ by at least two methods.

\section{Results}

\section{Sequencing and phylogenetic analysis}

The full coding sequences of the Korean DV-1 (43251; 10,179 nucleotides) and DV-4 (43257; 10,163 nucleotides) isolates were determined, and the serotypes of those viruses were confirmed by NCBI BLAST analysis. The phylogenetic analysis of the DV-1 and DV-4 strains was performed based on the full coding region (Fig. 1a and b). The DV-1 isolates from Korea fit into three of five previously defined genotypes: genotype I (43251, KP406802), genotype IV (KP406803), and genotype V (KP406801), based on 8.6-9.5\% nucleotide sequence divergence. In addition, the DV-4 strains were classified into genotype I (KP406806) and genotype II (43257) based on 5.7\% nucleotide sequence divergence. The strains most similar to our Korean isolates were DV-1 Singapore 2005 (EU081276, 99.5\%) to 43251,
DV-1 Indonesia 2008 (KC762641, 99.7\%) to KP406802, DV-1 Singapore 2012 (MF033197, 98.7\%) to KP406801, DV-1 Hawaii 2001 (DQ672564, 98.5\%) to KP406803, DV-4 Singapore 2005 (GQ398256, 98.9\%) to 43257, and DV-4 Philippines 1956 (AY947539, 99.9\%) to KP406806. All sequences files are available from the GenBank database (accession numbers MT597439 and MT459980).

\section{Sequence analysis}

Among the Korean DV-1 isolates, the nucleotide and amino acid sequence identity ranged from $90.5 \%$ to $98.8 \%$ and $96.4 \%$ to $99.4 \%$, respectively. The nucleotide and amino acid sequence identity among the DV-4 isolates was $94.3 \%$ and $96.8 \%$, respectively (Table 2 ). The amino acid sequence for each open reading frame of the Korean DV-1 and DV-4 isolates was compared with that of the most similar strain and the standard strain of each type (Tables 3 and 4). The region of the DV-1 isolates that was most variable, based on amino acid sequence comparisons (95.8-96.4\% identity) to EU848545 (the DV-1 standard strain), was in the prM protein. Compared with the most similar strain of each DV-1 isolate, the KP406801 strain exhibited the lowest overall sequence similarity (95.4-99.2\% identity). The region of the DV-4 isolates that differed the most from AF326573 (the DV-4 standard strain) was in the NS2A and NS1 proteins (95.4\% and $95.5 \%$ identity, respectively). However, amino acid changes in the motifs related to virulence and viability [24, 25] were not observed in either DV-1 or DV-4 (Supplementary Tables S2 and S3).

\section{Bayesian evolutionary analysis}

Rates of nucleotide substitution and TMRCA with ESS values above 200 were determined for the E genes of 70 DV-1 strains and 54 DV-4 strains (Fig. 2a and b). The number of nucleotide substitutions per site per year in the DV-1 strains was $5.58 \times 10^{-4}(95 \%$ high probability density [HPD] interval: $4.00 \times 10^{-4}$ to $\left.7.13 \times 10^{-4}\right)$, and the rate in the DV-4 strains was $6.72 \times 10^{-4}\left(95 \%\right.$ HPD interval: $5.52 \times 10^{-4}$ to $\left.7.94 \times 10^{-4}\right)$. The TMRCA of each epidemic strain, DV-1 43251 (genotype I), KP406802 (genotype I), KP406803 (genotype IV), and KP406801 (genotype V), was 10.8, $10.8,21.4$, and 16.9 years, respectively. The TMRCA of the DV-4 epidemic strain containing 43257 (genotype II) was 22 years. Genotype I of Korean DV-1 probably descended from a common ancestor that existed in Singapore during the period 2000-2006. KP406803, belonging to genotype $\mathrm{IV}$, formed a monophyletic group with the most probable ancestral origin in the Philippines and Hawaii during 1997-2006. The genotype V isolate from Korea (KP406801) is estimated to have emerged at least 42.3 years ago. The 
(a)

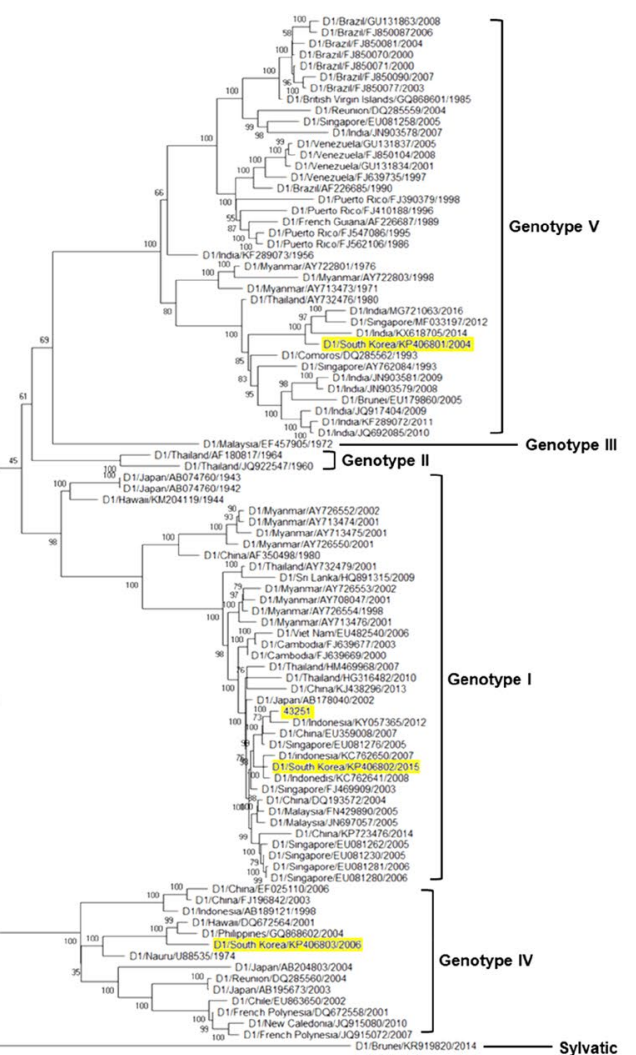

0050

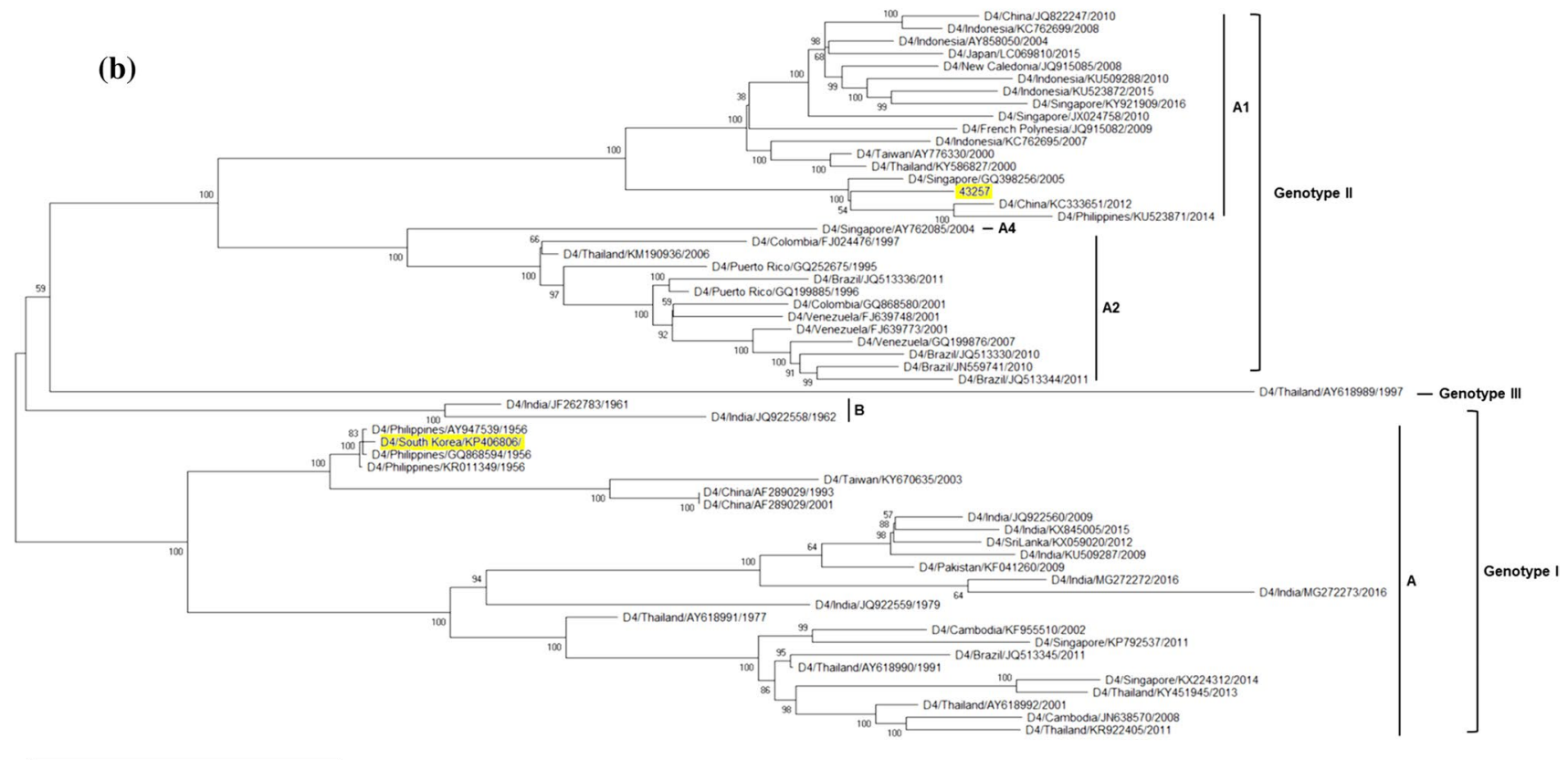

0,020

Fig. 1 Phylogenetic analysis of DV-1 and DV-4 using the maximumlikelihood method. The trees were constructed in MEGA-X using nucleotide sequences of the complete coding region. The percentage of bootstrap support determined from 1,000 replicates is shown for key nodes. The operational taxonomic unit (OTU) label for each strain consists of four parts separated by forward slashes (' $/$ )): serotype/country of collection/GenBank accession number/year of collection. The scale is the number of nucleotide substitutions per site along the branch. (a) DV-1, (b) DV-4 
Table 2 Nucleotide and amino acid sequence identity of the envelope genes and proteins of DV-1 and DV-4

\begin{tabular}{lllllll}
\hline \multirow{2}{*}{ Strain } & \multicolumn{5}{l}{ Sequence identity (\%) } \\
\cline { 2 - 7 } & KP406802 & 43251 & KP406803 & KP406801 & 43257 & KP406806 \\
\hline KP406802 & 98.79 & 91.25 & 90.57 & 65.21 & 64.67 \\
43251 & 99.39 & & 91.45 & 90.51 & 65.08 & 64.41 \\
KP406803 & 97.37 & 91.17 & & 90.77 & 64.27 & 63.40 \\
KP406801 & 96.57 & 96.36 & 97.37 & & 64.00 & 63.20 \\
43257 & 63.84 & 63.43 & 63.64 & 64.85 & & 94.34 \\
KP406806 & 62.83 & 62.42 & 62.42 & 63.23 & 96.77 & \\
\hline
\end{tabular}

The values below the diagonal spaces indicate amino acid sequence identity (\%), and the values above the diagonal spaces indicate nucleotide sequence identity (\%).

Table 3 Amino acid substitutions in DV-1 compared to the most similar strains and standard virus

\begin{tabular}{|c|c|c|c|c|c|c|c|c|c|c|c|c|}
\hline \multirow[t]{2}{*}{ Strain } & \multirow{2}{*}{$\begin{array}{l}\text { Reference } \\
\text { strain }\end{array}$} & \multirow[b]{2}{*}{$\begin{array}{l}\text { No. of sub- } \\
\text { stitutions } \\
\text { (\% iden- } \\
\text { tity) }\end{array}$} & \multicolumn{4}{|c|}{ Structural proteins } & \multicolumn{6}{|c|}{ Non-structural proteins } \\
\hline & & & $\begin{array}{l}\text { C } \\
(114)\end{array}$ & $\begin{array}{l}\text { prM } \\
(166)\end{array}$ & $\begin{array}{l}\mathrm{E} \\
(495)\end{array}$ & $\begin{array}{l}\text { NS1 } \\
(352)\end{array}$ & $\begin{array}{l}\text { NS2A } \\
(218)\end{array}$ & $\begin{array}{l}\text { NS2B } \\
(130)\end{array}$ & $\begin{array}{l}\text { NS3 } \\
(619)\end{array}$ & $\begin{array}{l}\text { NS4A } \\
(127)\end{array}$ & $\begin{array}{l}\text { NS4B } \\
(249)\end{array}$ & $\begin{array}{l}\text { NS5 } \\
\text { (899) }\end{array}$ \\
\hline \multirow[t]{2}{*}{43251} & EU848545 & & $\begin{array}{l}4 \\
(96.49)\end{array}$ & $\begin{array}{l}7 \\
(95.78)\end{array}$ & $\begin{array}{l}10 \\
(97.98)\end{array}$ & $\begin{array}{l}10 \\
(97.16)\end{array}$ & $\begin{array}{l}3 \\
(98.62)\end{array}$ & $\begin{array}{l}2 \\
(98.46)\end{array}$ & $\begin{array}{l}10 \\
(98.38)\end{array}$ & $\begin{array}{l}2 \\
(98.43)\end{array}$ & $\begin{array}{l}4 \\
(98.39)\end{array}$ & $\begin{array}{l}12 \\
(98.67)\end{array}$ \\
\hline & EU081276 ${ }^{\mathrm{b}}$ & & $\begin{array}{l}0 \\
(100)\end{array}$ & $\begin{array}{l}0 \\
(100)\end{array}$ & $\begin{array}{l}2 \\
(99.60)\end{array}$ & $\begin{array}{l}0 \\
(100)\end{array}$ & $\begin{array}{l}1 \\
(99.54)\end{array}$ & $\begin{array}{l}0 \\
(100)\end{array}$ & $\begin{array}{l}0 \\
(100)\end{array}$ & $\begin{array}{l}1 \\
(99.21)\end{array}$ & $\begin{array}{l}1 \\
(99.60)\end{array}$ & $\begin{array}{l}6 \\
(99.33)\end{array}$ \\
\hline \multirow[t]{2}{*}{ KР406801 } & EU848545 & & $\begin{array}{l}4 \\
(96.49)\end{array}$ & $\begin{array}{l}6 \\
(96.39)\end{array}$ & $\begin{array}{l}10 \\
(97.98)\end{array}$ & $\begin{array}{l}10 \\
(97.16)\end{array}$ & $\begin{array}{l}4 \\
(98.17)\end{array}$ & $\begin{array}{l}2 \\
(98.46)\end{array}$ & $\begin{array}{l}10 \\
(98.38)\end{array}$ & $\begin{array}{l}2 \\
(98.43)\end{array}$ & $\begin{array}{l}4 \\
(98.39)\end{array}$ & $\begin{array}{l}14 \\
(98.44)\end{array}$ \\
\hline & MF033197 & & $\begin{array}{l}5 \\
(95.61)\end{array}$ & $\begin{array}{l}4 \\
(97.59)\end{array}$ & $\begin{array}{l}13 \\
(97.37)\end{array}$ & $\begin{array}{l}9 \\
(97.44)\end{array}$ & $\begin{array}{l}10 \\
(95.41)\end{array}$ & $\begin{array}{l}1 \\
(99.23)\end{array}$ & $\begin{array}{l}11 \\
(98.22)\end{array}$ & $\begin{array}{l}4 \\
(96.85)\end{array}$ & $\begin{array}{l}5 \\
(97.99)\end{array}$ & $\begin{array}{l}24 \\
(97.33)\end{array}$ \\
\hline \multirow[t]{2}{*}{ KP406802 } & EU848545 & & $\begin{array}{l}4 \\
(96.49)\end{array}$ & $\begin{array}{l}7 \\
(95.78)\end{array}$ & $\begin{array}{l}10 \\
(97.98)\end{array}$ & $\begin{array}{l}10 \\
(97.16)\end{array}$ & $\begin{array}{l}3 \\
(98.62)\end{array}$ & $\begin{array}{l}2 \\
(98.46)\end{array}$ & $\begin{array}{l}11 \\
(98.22)\end{array}$ & $\begin{array}{l}2 \\
(98.43)\end{array}$ & $\begin{array}{l}3 \\
(98.80)\end{array}$ & $\begin{array}{l}11 \\
(98.78)\end{array}$ \\
\hline & KC762641 & & $\begin{array}{l}0 \\
(100)\end{array}$ & $\begin{array}{l}2 \\
(98.80)\end{array}$ & $\begin{array}{l}1 \\
(99.80)\end{array}$ & $\begin{array}{l}0 \\
(100)\end{array}$ & $\begin{array}{l}0 \\
(100)\end{array}$ & $\begin{array}{l}0 \\
(100)\end{array}$ & $\begin{array}{l}0 \\
(100)\end{array}$ & $\begin{array}{l}0 \\
(100)\end{array}$ & $\begin{array}{l}0 \\
(100)\end{array}$ & $\begin{array}{l}0 \\
(100)\end{array}$ \\
\hline \multirow[t]{2}{*}{ KP406803 } & EU848545 & & $\begin{array}{l}4 \\
(96.49)\end{array}$ & $\begin{array}{l}7 \\
(95.78)\end{array}$ & $\begin{array}{l}7 \\
(98.59)\end{array}$ & $\begin{array}{l}11 \\
(96.88)\end{array}$ & $\begin{array}{l}8 \\
(96.33)\end{array}$ & $\begin{array}{l}3 \\
(97.69)\end{array}$ & $\begin{array}{l}10 \\
(98.38)\end{array}$ & $\begin{array}{l}2 \\
(98.43)\end{array}$ & $\begin{array}{l}4 \\
(98.39)\end{array}$ & $\begin{array}{l}10 \\
(98.89)\end{array}$ \\
\hline & DQ472564 & & $\begin{array}{l}1 \\
(99.12)\end{array}$ & $\begin{array}{l}1 \\
(99.40)\end{array}$ & $\begin{array}{l}1 \\
(99.80)\end{array}$ & $\begin{array}{l}0 \\
(100)\end{array}$ & $\begin{array}{l}0 \\
(100)\end{array}$ & $\begin{array}{l}0 \\
(100)\end{array}$ & $\begin{array}{l}1 \\
(99.84)\end{array}$ & $\begin{array}{l}0 \\
(100)\end{array}$ & $\begin{array}{l}1 \\
(99.60)\end{array}$ & $\begin{array}{l}1 \\
(99.89)\end{array}$ \\
\hline
\end{tabular}

${ }^{\text {a }}$ DV-1 standard strain

${ }^{\mathrm{b}}$ the most similar DV-1 to each Korean isolate

TMRCA estimates and 95\% HPD intervals calculated from the Bayesian coalescent phylogenetic analysis were as follows: DV-4 genotype I, 84.4 years ago; genotype II, 83.4 years ago; genotype III, 112.0 years ago.

\section{Selection pressure}

Selection pressure was analyzed for the structural and nonstructural proteins of the DV-1 and DV-4 strains (Tables 5 and 6). The sites under positive or negative selection were identified based on statistical verification using at least two methods. Positive selection in DV-1 strains was observed in the C, prM, NS2A, and NS5 proteins, whereas positive selection in DV-4 strains was observed only in the non-structural proteins NS2A, NS3, and NS5. DV-4 had higher overall rates of negative selection than DV-1 in most structural and non-structural proteins.

\section{Discussion}

The incidence of global dengue outbreaks is growing at a very rapid rate, with a $400 \%$ increase in recent decades due to global warming, urbanization, and increased global travel [26]. Since 2010, the influx of global travelers infected with DV has been increasing rapidly in Korea [27], putting Korea 
Table 4 Amino acid substitutions in DV-4 compared to the most similar strains and standard virus

\begin{tabular}{|c|c|c|c|c|c|c|c|c|c|c|c|c|}
\hline \multirow[t]{2}{*}{ Strain } & \multirow{2}{*}{$\begin{array}{l}\text { Reference } \\
\text { strain }\end{array}$} & \multirow[b]{2}{*}{$\begin{array}{l}\text { No. of sub- } \\
\text { stitutions } \\
\text { (\% iden- } \\
\text { tity) }\end{array}$} & \multicolumn{4}{|c|}{ Structural proteins } & \multicolumn{6}{|c|}{ Non-structural proteins } \\
\hline & & & $\begin{array}{l}\mathrm{C} \\
(114)\end{array}$ & $\begin{array}{l}\text { prM } \\
(166)\end{array}$ & $\begin{array}{l}E \\
(495)\end{array}$ & $\begin{array}{l}\text { NS1 } \\
(352)\end{array}$ & $\begin{array}{l}\text { NS2A } \\
(218)\end{array}$ & $\begin{array}{l}\text { NS2B } \\
(130)\end{array}$ & $\begin{array}{l}\text { NS3 } \\
(618)\end{array}$ & $\begin{array}{l}\text { NS4A } \\
(127)\end{array}$ & $\begin{array}{l}\text { NS4B } \\
(245)\end{array}$ & $\begin{array}{l}\text { NS5 } \\
(900)\end{array}$ \\
\hline \multirow[t]{2}{*}{43257} & AF326573 & & $\begin{array}{l}4 \\
(96.49\end{array}$ & $\begin{array}{l}0 \\
(100)\end{array}$ & $\begin{array}{l}5 \\
(98.99)\end{array}$ & $\begin{array}{l}5 \\
(98.58)\end{array}$ & $\begin{array}{l}10 \\
(95.41)\end{array}$ & $\begin{array}{l}0 \\
(100)\end{array}$ & $\begin{array}{l}6 \\
(99.03)\end{array}$ & $\begin{array}{l}0 \\
(100)\end{array}$ & $\begin{array}{l}5 \\
(97.99)\end{array}$ & $\begin{array}{l}20 \\
(97.78)\end{array}$ \\
\hline & GQ398256 ${ }^{\mathrm{b}}$ & & $\begin{array}{l}1 \\
(99.12\end{array}$ & $\begin{array}{l}3 \\
(98.19)\end{array}$ & $\begin{array}{l}3 \\
(99.39)\end{array}$ & $\begin{array}{l}7 \\
(98.01)\end{array}$ & $\begin{array}{l}3 \\
(98.62)\end{array}$ & $\begin{array}{l}1 \\
(99.23)\end{array}$ & $\begin{array}{l}2 \\
(99.68)\end{array}$ & $\begin{array}{l}3 \\
(97.64)\end{array}$ & $\begin{array}{l}0 \\
(100)\end{array}$ & $\begin{array}{l}7 \\
(99.22)\end{array}$ \\
\hline \multirow[t]{2}{*}{ KР406806 } & AF326573 & & $\begin{array}{l}3 \\
(97.37\end{array}$ & $\begin{array}{l}4 \\
(97.59)\end{array}$ & $\begin{array}{l}14 \\
(97.17)\end{array}$ & $\begin{array}{l}16 \\
(95.45)\end{array}$ & $\begin{array}{l}7 \\
(96.79)\end{array}$ & $\begin{array}{l}4 \\
(96.92)\end{array}$ & $\begin{array}{l}8 \\
(98.71)\end{array}$ & $\begin{array}{l}3 \\
(97.64)\end{array}$ & $\begin{array}{l}3 \\
(98.80)\end{array}$ & $\begin{array}{l}8 \\
(99.11)\end{array}$ \\
\hline & AY947539 & & $\begin{array}{l}1 \\
(99.12\end{array}$ & $\begin{array}{l}4 \\
(97.59)\end{array}$ & $\begin{array}{l}2 \\
(99.60)\end{array}$ & $\begin{array}{l}1 \\
(99.72)\end{array}$ & $\begin{array}{l}0 \\
(100)\end{array}$ & $\begin{array}{l}1 \\
(99.23)\end{array}$ & $\begin{array}{l}0 \\
(100)\end{array}$ & $\begin{array}{l}1 \\
(99.21)\end{array}$ & $\begin{array}{l}1 \\
(99.60)\end{array}$ & $\begin{array}{l}0 \\
(100)\end{array}$ \\
\hline
\end{tabular}

a DV-4 standard strain

${ }^{\mathrm{b}}$ the most similar DV-4 to each Korean isolate

C, capsid; prM, pre-membrane; E, envelope; NS, non-structural

at high risk for epidemics of dengue disease. Therefore, DV must be continually monitored and characterized to cope with this impending threat. In this study, we conducted the first molecular, biological, and evolutionary analysis of DV-1 and DV-4 isolates from Korea.

The DV-1 strains were previously classified into five distinct genotypes (I-V) [28, 29]. Phylogenetic analysis based on the $\mathrm{E}$ protein and the complete coding region revealed that the DV-1 isolates in Korea belong to genotype I (43251, KP406802), genotype IV (KP406803), and genotype V (KP406801) (Fig 1a). The strains D1/Singapore/ EU081276/2005 and D1/Indonesia/KC762641/2008, which were the ones most similar to two Korean DV-1 isolates (43251 and KP406802; genotype I), were the major strains that caused dengue outbreaks in Singapore in 2005 and Indonesia in 2007, respectively [30-32]. Our results indicate that these viruses are still circulating in Southeast Asian countries more than 10 years later. The KP406803 isolate was grouped into the genotype IV clade, which also includes D1/Philippines/GQ868602/2004 and D1/Hawaii/ DQ672564/2001. Genotype IV of DV-1 was first isolated in the Philippines in 1974, and it has predominated in each epidemic in the South Pacific since 2000 [33]. Among the five DV-1 genotypes, genotype $\mathrm{V}$ has been reported to be the most virulent and to be strongly associated with DHF [9]. We identified one strain (KP406801) from this virulent genotype. As shown by our results, various DV-1 genotypes that have caused epidemics in other countries have been introduced into Korea, where they could cause disease outbreaks.

The substitution rate per site per year of the E protein in DV-1 was $5.58 \times 10^{-4}$, which is high for an RNA virus. The substitution rates for RNA viruses generally range from $10^{-6}$ to $10^{-4}$. The rate for DV-1 was similar to that reported previously for DV-2 strains isolated in Korea $\left(5.32 \times 10^{-4}\right)$ [34]. However, the isolation years differed significantly between the Korean DV-1 strains and the most similar strains, differing by 7 to 8 years, even though these strains shared a high degree of nucleotide sequence similarity (98.7-99.5\% identity) (Fig. 2a). The average TMRCAs of the DV-1 isolates from this study were 11 (43251 and KP406802), 21 (KP406803), and 17 years (KP406801) [23]. The TMRCA of previously reported DV-2 isolates from Korea (4 to 10 years) was shorter than those of the DV-1 and DV-4 strains we tested, although the overall substitution rates of the DV-2 strains were similar to those in this report [34]. These results suggest that some DV-1 genotypes with slow substitution rates caused concomitant DV outbreaks in Southeast Asia, including in Singapore, and were then introduced into Korea [32, 35].

Among the three genotypes (I-III) of the DV-4 serotype, the Korean DV-4 isolates belong to genotype I (KP406806) and genotype II (43257) (Fig. 1b). The strain most similar to KP406806 is D4/Philippines/AY947539/1956, a representative strain that has been found consistently in China and Taiwan from about 60 years ago until the 2000s. The DV-4 43257 strain, which was isolated from a Korean traveling to the Philippines in 2010, has the highest nucleotide sequence similarity to DV-4 strains circulating in Singapore in 2005. DV-4 genotype II is the predominant genotype in Singapore, indicating that it was introduced into Korea via the Philippines [32]. The substitution rate per site per year of the DV-4 strains was $6.72 \times 10^{-4}$, which was as fast as that of previously reported DV-1 and DV-2 strains [34]. The TMRCA analysis showed that this strain evolved within 20 years. Like the DV-1 isolates, DV-4 strains have been consistently circulating in Southeast Asia 

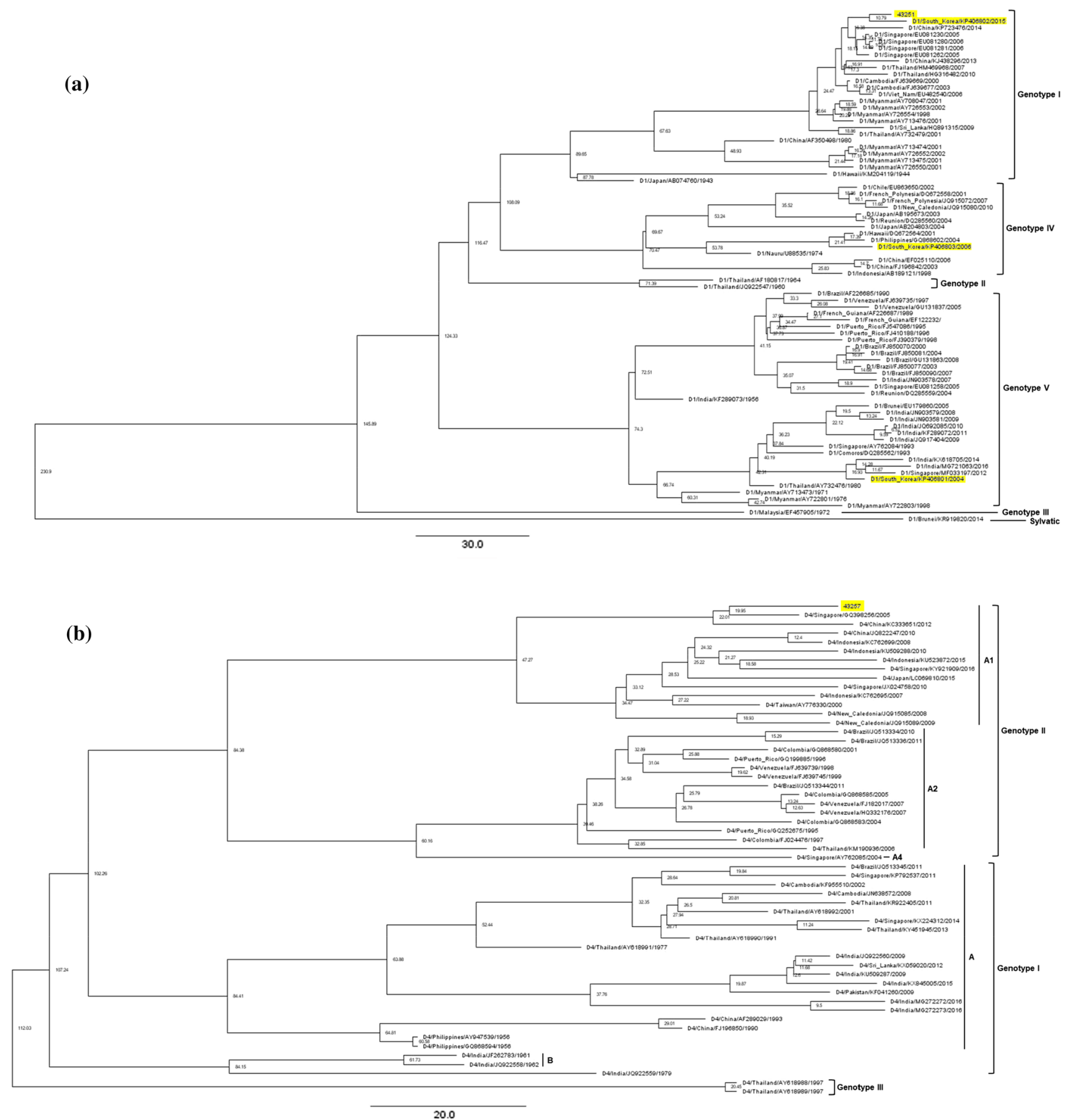

Fig. 2 Bayesian evolutionary analysis of DV-1 and DV-4 in Korea. The relationships of DV-1 and DV-4 strains were inferred based on complete $\mathrm{E}$ gene nucleotide sequences using a relaxed uncorrelated lognormal molecular clock with a Bayesian skyline coalescent prior. The Korean DV sequences from the present study are indicated in

without significant mutation for a long time, even though we found DV-4 to have a rapid substitution rate, similar to those of DV-1 and DV-2 in Korea.

Several amino acid sequence motifs affecting viability and virulence have been found in DV proteins. An S112A yellow. The estimated 95\% HDP values for the TMRCA are indicated at the node. Strains are labeled as follows: serotype/country of collection/GenBank accession number/year of collection for each strain. (a) DV-1, (b) DV-4

substitution in the prM protein inhibits the assembly of replicon particles, and a T193A mutation in the E protein reduces the infectivity of DV-1 tenfold [24]. An R888 mutation results in incorrect localization of NS5, affecting the synthesis of negative-stranded RNA [25]. A 40-aa deletion 
Table 5 Selection pressure analysis of DV-1

\begin{tabular}{|c|c|c|c|c|c|c|c|c|c|c|c|}
\hline \multirow{2}{*}{\multicolumn{2}{|c|}{$\begin{array}{l}\text { Type of selection } \\
\text { pressure }\end{array}$}} & \multicolumn{3}{|c|}{ Structural proteins } & \multicolumn{7}{|c|}{ Non-structural proteins } \\
\hline & & $\begin{array}{l}\text { C } \\
(114)\end{array}$ & $\begin{array}{l}\text { prM } \\
(166)\end{array}$ & $\begin{array}{l}\mathrm{E} \\
(495)\end{array}$ & $\begin{array}{l}\text { NS1 } \\
(352)\end{array}$ & $\begin{array}{l}\text { NS2A } \\
(218)\end{array}$ & $\begin{array}{l}\text { NS2B } \\
(128)\end{array}$ & $\begin{array}{l}\text { NS3 } \\
(618)\end{array}$ & $\begin{array}{l}\text { NS4A } \\
(127)\end{array}$ & $\begin{array}{l}\text { NS4B } \\
(246)\end{array}$ & $\begin{array}{l}\text { NS5 } \\
(900)\end{array}$ \\
\hline Positive & $\begin{array}{l}\text { Number } \\
(\%)\end{array}$ & $\begin{array}{l}1 \\
(0.9)\end{array}$ & $\begin{array}{l}2 \\
(1.2)\end{array}$ & $\begin{array}{l}0 \\
(0)\end{array}$ & $\begin{array}{l}0 \\
(0)\end{array}$ & $\begin{array}{l}1 \\
(0.5)\end{array}$ & $\begin{array}{l}0 \\
(0)\end{array}$ & $\begin{array}{l}0 \\
(0)\end{array}$ & $\begin{array}{l}0 \\
(0)\end{array}$ & $\begin{array}{l}0 \\
(0)\end{array}$ & $\begin{array}{l}3 \\
(0.3)\end{array}$ \\
\hline Negative & $\begin{array}{l}\text { Number } \\
(\%)\end{array}$ & $\begin{array}{l}22 \\
(19.3)\end{array}$ & $\begin{array}{l}70 \\
(42.2)\end{array}$ & $\begin{array}{l}203 \\
(41.0)\end{array}$ & $\begin{array}{l}146 \\
(41.5)\end{array}$ & $\begin{array}{l}94 \\
(43.1)\end{array}$ & $\begin{array}{l}60 \\
(46.9)\end{array}$ & $\begin{array}{l}281 \\
(45.5)\end{array}$ & $\begin{array}{l}61 \\
(48.0)\end{array}$ & $\begin{array}{l}115 \\
(46.7)\end{array}$ & $\begin{array}{l}397 \\
(44.1)\end{array}$ \\
\hline
\end{tabular}

C, capsid; prM, pre-membrane; E, envelope; NS, non-structural

\begin{tabular}{|c|c|c|c|c|c|c|c|c|c|c|c|}
\hline \multirow{2}{*}{\multicolumn{2}{|c|}{$\begin{array}{l}\text { Type of selection } \\
\text { pressure }\end{array}$}} & \multicolumn{3}{|c|}{ Structural proteins } & \multicolumn{7}{|c|}{ Non-structural proteins } \\
\hline & & \multirow{2}{*}{$\begin{array}{l}\mathrm{C} \\
(114) \\
0 \\
(0)\end{array}$} & \multirow{2}{*}{$\begin{array}{l}\text { prM } \\
(166)\end{array}$} & \multirow{2}{*}{$\begin{array}{l}\mathrm{E} \\
(495) \\
0 \\
(0)\end{array}$} & \multirow{2}{*}{$\begin{array}{l}\begin{array}{l}\text { NS1 } \\
(352)\end{array} \\
0 \\
(0)\end{array}$} & \multirow{2}{*}{$\begin{array}{l}\begin{array}{l}\text { NS2A } \\
(218)\end{array} \\
1 \\
(0.5)\end{array}$} & \multirow{2}{*}{$\begin{array}{l}\begin{array}{l}\text { NS2B } \\
(128)\end{array} \\
0 \\
(0)\end{array}$} & \multirow{2}{*}{$\begin{array}{l}\begin{array}{l}\text { NS3 } \\
(618)\end{array} \\
1 \\
(0.2)\end{array}$} & \multirow{2}{*}{$\begin{array}{l}\begin{array}{l}\text { NS4A } \\
(127)\end{array} \\
0 \\
(0)\end{array}$} & \multirow{2}{*}{$\begin{array}{l}\begin{array}{l}\text { NS4B } \\
(246)\end{array} \\
0 \\
(0)\end{array}$} & \multirow{2}{*}{$\begin{array}{l}\begin{array}{l}\text { NS5 } \\
(900)\end{array} \\
3 \\
(0.3)\end{array}$} \\
\hline ositive & $\begin{array}{l}\text { Num } \\
(\%)\end{array}$ & & & & & & & & & & \\
\hline egative & $\begin{array}{l}\text { Number } \\
(\%)\end{array}$ & $\begin{array}{l}51 \\
(44.7)\end{array}$ & $\begin{array}{l}121 \\
(72.9)\end{array}$ & $\begin{array}{l}360 \\
(72.7)\end{array}$ & $\begin{array}{l}251 \\
(71.3)\end{array}$ & $\begin{array}{l}160 \\
(73.4)\end{array}$ & $\begin{array}{l}98 \\
(76.6)\end{array}$ & $\begin{array}{l}487 \\
(78.8)\end{array}$ & $\begin{array}{l}100 \\
(78.7)\end{array}$ & $\begin{array}{l}192 \\
(78.0)\end{array}$ & $\begin{array}{l}649 \\
(72.1)\end{array}$ \\
\hline
\end{tabular}

C, capsid; prM, pre-membrane; E, envelope; NS, non-structural
Table 6 Selection pressure analysis of DV-4 pressure should be evaluated carefully to prepare for future DV epidemics. Interestingly, significantly fewer sites in DV-1 were under negative selective pressure than in DV-2 and DV-4. This significant difference suggests that the DV-1 strains have a more stable evolutionary status than the DV-2 and DV-4 strains [44].

In this study, we performed molecular and evolutionary analysis of DV-1 and DV-4 isolates from Korea. Because many global travelers with dengue infection are asymptomatic or have mild symptoms, the actual incidence of DV infection in Koreans is probably higher than the number of reported cases. Nevertheless, considering the extremely limited amount of information that was previously available about DV-1 and DV-4 isolates in Korea, this study has provided the first comprehensive molecular, phylogenetic, and evolutionary information about DV-1 and DV-4 strains in Korea. Various genotypes of DV-1 and DV-4 with distinct characteristics have been introduced into Korea, and some of them could cause autochthonous outbreaks in Korea. Therefore, further characterization and surveillance of DV should be performed.

Acknowledgements The pathogen resources (NCCP43251 and NCCP43257) for this study were provided by the National Culture Collection for Pathogens.

Author contributions EHH drafted the manuscript. GK, HC, and HO performed the data analysis. JHP and GHH revised the manuscript. JJH and BSK designed and supervised the experiments. All authors read and approved the final manuscript.

Funding This study was funded by a grant from the Defense Acquisition Program Administration (ADD-911255201), Republic of Korea. 


\section{Compliance with ethical standards}

Conflict of interest All authors declare that they have no conflict of interest.

Ethical approval This article does not contain any studies with animals or human participants performed by any of the authors.

Open Access This article is licensed under a Creative Commons Attribution 4.0 International License, which permits use, sharing, adaptation, distribution and reproduction in any medium or format, as long as you give appropriate credit to the original author(s) and the source, provide a link to the Creative Commons licence, and indicate if changes were made. The images or other third party material in this article are included in the article's Creative Commons licence, unless indicated otherwise in a credit line to the material. If material is not included in the article's Creative Commons licence and your intended use is not permitted by statutory regulation or exceeds the permitted use, you will need to obtain permission directly from the copyright holder. To view a copy of this licence, visit http://creativecommons.org/licenses/by/4.0/.

\section{References}

1. Wilder-Smith A, Ooi EE, Horstick O, Wills B (2019) Dengue. Lancet 393(10169):350-363. https://doi.org/10.1016/S0140 $-6736(18) 32560-1$

2. Guzman MG, Harris E (2015) Dengue. Lancet 385(9966):453-465

3. Guo C, Zhou Z, Wen Z, Liu Y, Zeng C, Xiao D, Ou M, Han Y, Huang S, Liu D (2017) Global epidemiology of dengue outbreaks in 1990-2015: a systematic review and meta-analysis. Front Cell Infect Microbiol 7:317

4. Ramos-Castaneda J, dos Santos FB, Martinez-Vega R, de Araujo JMG, Joint G, Sarti E (2017) Dengue in Latin America: systematic review of molecular epidemiological trends. PLoS Negl Trop Diseases 11(1):e0005224

5. Struchiner CJ, Rocklöv J, Wilder-Smith A, Massad E (2015) Increasing dengue incidence in Singapore over the past 40 years: population growth, climate and mobility. PLoS ONE 10(8):e0136286

6. Shepard DS, Undurraga EA, Halasa YA (2013) Economic and disease burden of dengue in Southeast Asia. PLoS Negl Trop Dis 7(2):e2055

7. Organization WH (2014) Dengue and severe dengue. World Health Organization. Regional Office for the Eastern Mediterranean

8. Lambrechts L, Fansiri T, Pongsiri A, Thaisomboonsuk B, Klungthong C, Richardson JH, Ponlawat A, Jarman RG, Scott TW (2012) Dengue-1 virus clade replacement in Thailand associated with enhanced mosquito transmission. J Virol 86(3):1853-1861

9. Rico-Hesse R (2003) Microevolution and virulence of dengue viruses. Adv Virus Res 59:315

10. Srikiatkhachorn A, Mathew A, Rothman AL (2017) Immunemediated cytokine storm and its role in severe dengue. Semin Immunopathol 39(5):563-574. https://doi.org/10.1007/s0028 1-017-0628-y

11. Zou C, Huang C, Zhang J, Wu Q, Ni X, Sun J, Dai J (2019) Virulence difference of five type I dengue viruses and the intrinsic molecular mechanism. PLoS Negl Trop Dis 13(3):e0007202

12. Prestwood TR, Prigozhin DM, Sharar KL, Zellweger RM, Shresta S (2008) A mouse-passaged dengue virus strain with reduced affinity for heparan sulfate causes severe disease in mice by establishing increased systemic viral loads. J Virol 82(17):8411-8421
13. Cho K-h, Park S-Y, Lee W-C, Lee M-J, Lee J-b (2018) International travel and exotic dengue fever in South Korea from 2006 to 2015. Jpn J Infect Dis 71(5):378-381

14. Jeong YE, Lee WC, Cho JE, Han MG, Lee WJ (2016) Comparison of the Epidemiological Aspects of Imported Dengue Cases between Korea and Japan, 2006-2010. Osong Public Health Res Perspect 7(1):71-74. https://doi.org/10.1016/j.phrp.2015.12.001

15. Lee H, Kim JE, Lee S, Lee CH (2018) Potential effects of climate change on dengue transmission dynamics in Korea. PLoS ONE 13(6):e0199205. https://doi.org/10.1371/journal.pone.0199205

16. Park G-H, Kim SI, Cho SW, Cho S-R, Lee S-J, Kim HK, Koo H-N, Lee W-G, Cho S-H, Kim G-H (2018) Seasonal distribution of mosquitoes according to habitat environment (2016-2018). Korean J Appl Entomol 57(4):381-392

17. Yung C-F, Lee K-S, Thein T-L, Tan L-K, Gan VC, Wong JGX, Lye DC, Ng L-C, Leo Y-S (2015) Dengue serotype-specific differences in clinical manifestation, laboratory parameters and risk of severe disease in adults, Singapore. Am J Trop Med Hyg 92(5):999-1005. https://doi.org/10.4269/ajtmh.14-0628

18. Nisalak A, Endy TP, Nimmannitya S, Kalayanarooj S, Scott RM, Burke DS, Hoke CH, Innis BL, Vaughn DW (2003) Serotypespecific dengue virus circulation and dengue disease in Bangkok, Thailand from 1973 to 1999. Am J Trop Med Hyg 68(2):191-202

19. Cruz CD, Torre A, Troncos G, Lambrechts L, Leguia M (2016) Targeted full-genome amplification and sequencing of dengue virus types 1-4 from South America. J Virol Methods 235:158-167

20. Kumar S, Stecher G, Li M, Knyaz C, Tamura K (2018) MEGA X: molecular evolutionary genetics analysis across computing platforms. Mol Biol Evol 35(6):1547-1549. https://doi.org/10.1093/ molbev/msy096

21. Weaver S, Shank SD, Spielman SJ, Li M, Muse SV, Kosakovsky Pond SL (2018) Datamonkey 2.0: a modern web application for characterizing selective and other evolutionary processes. Mol Biol Evol 35(3):773-777. https://doi.org/10.1093/molbev/msx335

22. Dash PK, Sharma S, Soni M, Agarwal A, Sahni AK, Parida M (2015) Complete genome sequencing and evolutionary phylogeography analysis of Indian isolates of Dengue virus type 1. Virus Res 195:124-134

23. Yohan B, Wardhani P, Trimarsanto H, Aryati A, Sasmono RT (2018) Genomic analysis of dengue virus serotype 1 (DENV-1) genotypes from Surabaya, Indonesia. Virus Genes 54(3):461-465

24. Ahmad Z, Poh CL (2019) The conserved molecular determinants of virulence in dengue virus. Int J Med Sci 16(3):355-365. https ://doi.org/10.7150/ijms.29938

25. Tay MY, Smith K, Ng IH, Chan KW, Zhao Y, Ooi EE, Lescar J, Luo D, Jans DA, Forwood JK, Vasudevan SG (2016) The C-terminal 18 amino acid region of Dengue Virus NS5 regulates its subcellular localization and contains a conserved arginine residue essential for infectious virus production. PLoS Pathog 12(9):e1005886. https://doi.org/10.1371/journal.ppat.1005886

26. Global Burden of Disease Cancer C, Fitzmaurice C, Allen C, Barber RM, Barregard L, Bhutta ZA et al (2017) Global, regional, and national cancer incidence, mortality, years of life lost, years lived with disability, and disability-adjusted life-years for 32 cancer groups, 1990 to 2015: a systematic analysis for the global burden of disease study. JAMA Oncol 3(4):524-548. https://doi. org/10.1001/jamaoncol.2016.5688

27. Miki S, Lee W-C, Lee M-J (2017) A comparative study of the trends of imported Dengue cases in Korea and Japan 2011-2015. J Clin Med Res 9(7):650

28. Goncalvez AP, Escalante AA, Pujol FH, Ludert JE, Tovar D, Salas RA, Liprandi F (2002) Diversity and evolution of the envelope gene of dengue virus type 1. Virology 303(1):110-119 
29. Teoh B-T, Sam S-S, Abd-Jamil J, AbuBakar S (2010) Isolation of ancestral sylvatic dengue virus type 1, Malaysia. Emerg Infect Dis 16(11):1783

30. Low JG, Ooi E-E, Tolfvenstam T, Leo Y-S, Hibberd ML, Ng L-C, Lai Y-L, Yap G, Li C, Vasudevan SG (2006) Early Dengue infection and outcome study (EDEN)-study design and preliminary findings. Ann Acad Med Singap 35(11):783

31. Sasmono RT, Wahid I, Trimarsanto H, Yohan B, Wahyuni S, Hertanto M, Yusuf I, Mubin H, Ganda IJ, Latief R (2015) Genomic analysis and growth characteristic of dengue viruses from Makassar, Indonesia. Infect Genet Evol 32:165-177

32. Lee K-S, Lo S, Tan SS-Y, Chua R, Tan L-K, Xu H, Ng L-C (2012) Dengue virus surveillance in Singapore reveals high viral diversity through multiple introductions and in situ evolution. Infect Genet Evol 12(1):77-85. https://doi.org/10.1016/j.meegid.2011.10.012

33. Sun Y, Meng S (2013) Evolutionary history and spatiotemporal dynamics of dengue virus type 1 in Asia. Infect Genet Evol 16:19-26. https://doi.org/10.1016/j.meegid.2013.01.013

34. Hwang EH, Kim G, Oh H, An YJ, Kim J, Kim JH, Hwang ES, Park JH, Hong J, Koo BS (2020) Molecular and evolutionary analysis of dengue virus serotype 2 isolates from Korean travelers in 2015. Arch Virol 165(8):1739-1748. https://doi.org/10.1007/ s00705-020-04653-z

35. Koo C, Tien WP, Xu H, Ong J, Rajarethinam J, Lai YL, Ng L-C, Hapuarachchi HC (2018) Highly selective transmission success of dengue virus type 1 lineages in a dynamic virus population: an evolutionary and fitness perspective. iScience 6:38-51

36. Falgout B, Miller RH, Lai CJ (1993) Deletion analysis of dengue virus type 4 nonstructural protein NS2B: identification of a domain required for NS2B-NS3 protease activity. J Virol 67(4):20342042. https://doi.org/10.1128/jvi.67.4.2034-2042.1993

37. Blaney JE Jr, Johnson DH, Manipon GG, Firestone CY, Hanson CT, Murphy BR, Whitehead SS (2002) Genetic basis of attenuation of dengue virus type 4 small plaque mutants with restricted replication in suckling mice and in SCID mice transplanted with human liver cells. Virology 300(1):125-139. https://doi. org/10.1006/viro.2002.1528
38. Zhang X, Jia R, Shen H, Wang M, Yin Z, Cheng A (2017) Structures and functions of the envelope glycoprotein in flavivirus infections. Viruses. https://doi.org/10.3390/v9110338

39. Tazeen A, Afreen N, Abdullah M, Deeba F, Haider S, Kazim S, Ali S, Naqvi I, Broor S, Ahmed A (2017) Occurrence of coinfection with dengue viruses during 2014 in New Delhi, India. Epidemiol Infect 145(1):67-77

40. Duvvuri VRSK, Duvvuri B, Cuff WR, Wu GE, Wu J (2009) Role of positive selection pressure on the evolution of H5N1 hemagglutinin. Genom Proteom Bioinform 7(1-2):47-56. https://doi. org/10.1016/S1672-0229(08)60032-7

41. De Maio FA, Risso G, Iglesias NG, Shah P, Pozzi B, Gebhard LG, Mammi P, Mancini E, Yanovsky MJ, Andino R, Krogan N, Srebrow A, Gamarnik AV (2016) The Dengue Virus NS5 protein intrudes in the cellular spliceosome and modulates splicing. PLoS Pathog 12(8):e1005841. https://doi.org/10.1371/journ al.ppat.1005841

42. Xie X, Gayen S, Kang C, Yuan Z, Shi P-Y (2013) Membrane topology and function of dengue virus NS2A protein. J Virol 87(8):4609-4622

43. Patil J, Cherian S, Walimbe A, Patil B, Sathe P, Shah P, Cecilia D (2011) Evolutionary dynamics of the American African genotype of dengue type 1 virus in India (1962-2005). Infect Genet Evol 11(6): 1443-1448

44. Behura SK, Severson DW (2013) Nucleotide substitutions in dengue virus serotypes from Asian and American countries: insights into intracodon recombination and purifying selection. BMC Microbiol 13(1):37. https://doi.org/10.1186/1471-2180-13-37

Publisher's Note Springer Nature remains neutral with regard to jurisdictional claims in published maps and institutional affiliations. 